УДК 338.242 .2

DOI: https://doi.org/10.26642/jen-2019-3(89)-35-40

О.В. Орлова-Курилова, к.е.н., доц. Луганський національний аграрний університет

І.А. Гнатенко, к.е.н., доц.

Київький національний університет технологій та дизайну

В.О. Рубежанська, к.е.н., асистент

Луганський національний університет імені Тараса Шевченка

\title{
Державне регулювання інноваційної діяльності підприємництва як напрям забезпечення сталого розвитку економіки країни
}

\begin{abstract}
У період радикальних реформувань та соціально-економічних перетворень в Украӥні, формування зовнішньої політики, спрямованої на тісну співпрацю з іншими європейськими державами, вітчизняним науковиям та практикам слід зосередитися на головних пріоритетах формування національної політики, одним з яких є державне регулювання інновачійних процесів у вітчизняному підприємництві. Державне регулювання інноваційної діяльності являє собою достатньо важкий та довготривалий процес, який потребує застосування арсеналу дій зі змічнення потенціалу та формування світового позитивного іміджу вітчизняного підприємництва. Особливо важливим завданням є формування таких напрямів державного регулювання, щзо були б вчасними та адаптивними до зовнішніх умов, в яких функціонують украӥнські інноваційні підприємства. У статті здійснено систематизацію факторів зовнішнього середовища, щзо сприяють та перешкоджають інновачійній діяльності. Крім того, авторами зазначено про те, щзо існуюча в Україні система державного регулювання інноваційноі діяльності суб'єктів господарювання не задовольняє вимоги сучасного розвитку суспільних відносин $i$ з иієї причини не може вважатися ефективною. У зв'язку з ичм, у статті запропоновано заходи з удосконалення зазначеної системи, які містять такі напрями, як: зміна структури товарного виробництва на користь обробних галузей, створення умов для підвищення доходів працюючого населення та, відповідно, росту купівельної спроможності, створення повноцінної інвестиційної інфраструктури. Авторами розроблено модель регулювання інноваційною діяльністю підприємниџтва на основі запропонованих рекомендацій. У статті визначено пряму залежність державного регулювання інноваційної діяльності підприсмництва від рівня регулювання розвитку інтелектуального потенціалу крайни та запропоновано математичну модель оцінювання ефективності регулювання останнім. Авторами зроблено висновок про важливість державного регулювання у інноваційній сфері з метою забезпечення достатнього рівня конкурентоспроможності економіки крайни на світовому рівні, а також виокремлено основні напрями регулювання, щчо потребують уваги $з$ боку органів державної влади.
\end{abstract}

Ключові слова: інновачія; інноваційна діяльність; інноваційне підприємництво; державне регулювання; інтелектуальний потенціал; модель.

Актуальність теми. Важливою детермінантою розвитку сучасного господарського комплексу України є пошук ефективних шляхів щодо дієвого державного регулювання інноваційних процесів у підприємницькій діяльності. Тим паче, що постійні зміни, що відбуваються у світовому суспільстві, характеризуються дією низки факторів, до яких можна зарахувати процеси глобалізації, інтеграції, розвитку високих технологій та наукоємних галузей. Тому становлення інноваційно-орієнтованого вітчизняного підприємництва і проведення структурної перебудови господарства України вимагає активної участі науковців у розробці та впровадженні інноваційних підприємницьких процесів. Отже, без суттєвих позитивних зрушень у сфері інтенсифікації інноваційних відносин у підприємницькій діяльності сталий розвиток економіки України є неможливим. Враховуючи тривалий досвід різнобічної державної підтримки функціонування інноваційного підприємництва у європейських країнах світу, слід визначити, що наша країна тільки починає створювати умови для його розвитку: формуються центри інфраструктурної підтримки інноваційних підприємств; впроваджуються національні, регіональні та місцеві програми підтримки розвитку; переглядаються податкові важелі їх діяльності тощо. Проте, як свідчать результати діяльності зазначених підприємств, ці заходи $є$ не достатньо ефективними та не дають відчутної дії. Звертає на себе увагу і той факт, що реалізація державної та місцевих програм підтримки розвитку підприємництва досі здійснюється фрагментарно та характеризується низьким залученням напрямів стосовно державної підтримки інноваційної діяльності. У зв'язку з цим актуальним завданням $є$ акцентуація вектора дослідження саме на наукове обгрунтування теоретико-методологічних засад та практичних рекомендацій щодо формування механізмів державного регулювання інноваційних процесів у підприємницькій діяльності. 
Аналіз останніх досліджень та публікації, на які спирається автор. Дослідженню сутності інновацій та інноваційного підприємництва присвячено публікації С.Бірюченко [1], В.Коюди та Л.Лисенко [2], Д.Крикуненко [3], О.Маслак [4], П.Друкера [5], О.Тарасової [6], Р.Фатхутдинова [7], Л.Чумак [8], Й.Шумпетера [9] та ін. Важливість державного регулювання інноваційних процесів висвітлено в роботах А.Амоши [10], В.Бурлаки [11], І.Кукси [12], І.Мойсеєнко [13], О.Поліщук [14], М.Семикіної та В.Гунько [15], О.Файчук [16], Л.Федулової [17] та інших науковців.

Віддаючи належне проведеним дослідженням вказаних вище науковців, слід зазначити про відсутність єдиного теоретико-методологічного підходу до розробки моделі державного регулювання інноваційної діяльності суб'єктів господарювання.

Метою статті с теоретичне обгрунтування ефективних заходів з удосконалення системи державного регулювання інноваційних процесів у вітчизняному підприємництві.

Викладення основного матеріалу. Тенденції розвитку національного господарства свідчать про підвищений вплив інноваційної діяльності на темпи економічного розвитку. На світовому ринку продукти інтелектуальної праці мають більш високу вартість відносно інших сфер економічної діяльності. Вимоги ринку диктують необхідність створення умов для широкого використання нововведень, підсилення інноваційної активності. При цьому необхідно враховувати фактори, які позитивно та негативно впливають на інноваційну діяльність суб'єктів господарювання (рис. 1).

\begin{tabular}{|c|c|c|c|}
\hline \multicolumn{4}{|c|}{ Фактори, що сприяють інноваційній діяльності } \\
\hline $\begin{array}{l}\text { Наявність необхідної } \\
\text { інфраструктури } \\
\text { інноваційного } \\
\text { підприємництва, } \\
\text { резерву фінансових та } \\
\text { матеріально-технічних } \\
\text { засобів, прогресивних } \\
\text { технологій } \\
\text { виробництва }\end{array}$ & $\begin{array}{l}\text { Державна підтримка } \\
\text { інноваційного } \\
\text { підприємництва, } \\
\text { законодавчі міри, що } \\
\text { сприяють } \\
\text { інноваційній } \\
\text { діяльності (пільги) }\end{array}$ & $\begin{array}{l}\text { Демократичний стиль } \\
\text { управління, гнучкість } \\
\text { організаційних } \\
\text { структур, переважання } \\
\text { горизонтальних потоків } \\
\text { інформації, } \\
\text { децентралізація, } \\
\text { самопланування, } \\
\text { орієнтація } \\
\text { довгострокову } \\
\text { окупність }\end{array}$ & $\begin{array}{l}\text { Моральне заохочення, } \\
\text { суспільне визнанн, } \\
\text { забезпечення } \\
\text { можливості } \\
\text { самореалізації, } \\
\text { нормальний } \\
\text { психологічний клімат у } \\
\text { колективі }\end{array}$ \\
\hline $5 \quad \square$ & P & 4 & 3 \\
\hline $\begin{array}{c}\text { Економічні та } \\
\text { технологічні фактори }\end{array}$ & $\begin{array}{c}\text { Політичні та правові } \\
\text { фактори }\end{array}$ & Організаційні фактори & $\begin{array}{c}\text { Соціально-психологічні } \\
\text { фактори }\end{array}$ \\
\hline$\square \quad 5$ & $\square \quad 5$ & $\not$ & $\square \quad 5$ \\
\hline $\begin{array}{l}\text { Недостатність } \\
\text { фінансових засобів для } \\
\text { реалізації } \\
\text { iнвестиційних проектів; } \\
\text { слабкість матеріально- } \\
\text { та науково-технічної } \\
\text { бази; } \\
\text { технологія виробництва }\end{array}$ & $\begin{array}{l}\text { Обмеження } 3 \text { боку } \\
\text { антимонопольного, } \\
\text { податкового, } \\
\text { патентно- } \\
\text { ліцензійного } \\
\text { законодавства }\end{array}$ & $\begin{array}{l}\text { Надлишкова } \\
\text { централізація, } \\
\text { авторитарний } \\
\text { управління, } \\
\text { переважання } \\
\text { вертикальних п потоків } \\
\text { iнформації, важкість } \\
\text { міжорганізаційної } \\
\text { взасмодії, жорсткість у } \\
\text { плануванні, орієнтація } \\
\text { на короткострокову } \\
\text { окупність }\end{array}$ & 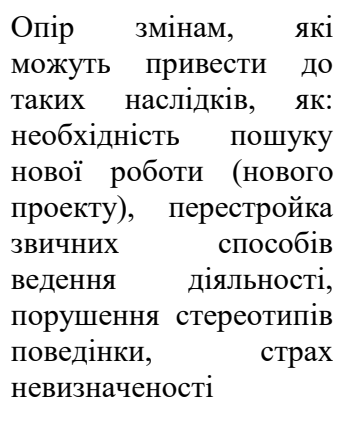 \\
\hline
\end{tabular}

Довідка: розробка авторів

\section{Рис. 1. Фактори впливу на інноваціийну діяльність підприємств}

Світовий досвід інноваційного розвитку свідчить про те, що інновації є оптимальним шляхом науково-технічного переозброєння та поетапної диверсифікації виробництва. При цьому можливими напрямами активізації інноваційної активності могли би стати такі: створення стабільного законодавства, яке має забезпечувати державні гарантії захисту вітчизняних та іноземних інвестицій протягом тривалого часу; створення сприятливого інноваційно-інвестиційного клімату для реалізації пріоритетних державних програм та інвестиційних проектів; сприяння залученню продуктивного прямого іноземного 
капіталу до сфери матеріального виробництва та встановлення державного контролю за його використанням; створення сприятливих умов для розвитку спільних підприємств, які займаються виробництвом тощо [12; 18$]$.

Слід окремо наголосити на тому, що запорукою підвищення рівня розвитку економіки у будь-якій країні, у тому числі й в Україні, $є$ ефективне державне регулювання інноваційної діяльності підприємств. Зокрема, держава як організація володіє конкурентними перевагами в реалізації засобів регуляторного випливу (примусу, контролю, відповідальності, покарання), що за вдалого їх застосування підсилює результативність інноваційного розвитку національного підприємництва. Крім того, комерціалізація будьякого інноваційного проекту передбачає наявність гаранта, який би фіксував та захищав інтелектуальне право, тож держава у цьому сенсі є зовнішньою силою, яка наглядає за дотриманням прав суб'єктів підприємницької діяльності, які комерціалізують ідею [19]. Однак існуюча в Україні система державного регулювання інноваційної діяльності суб'єктів господарювання не задовольняє вимоги сучасного розвитку суспільних відносин і з цієї причини не може вважатися ефективною. У зв’язку з цим, дана система потребує певних заходів з ії удосконалення, що дозволять змінити існуючу тенденцію незатребуваності фахівців, готових до створення та запровадження нових прийомів регулювання, технічних пристроїв, технічних і соціальних технологій, створити позитивний імпульс для інноваційного розвитку нашої країни. Для досягнення економічного зростання потрібні істотні зміни основних макроструктурних пропорцій, зокрема, зміна структури товарного виробництва на користь обробних галузей. 3 огляду на обмеженість державних ресурсів, необхідно визначити галузі економіки та виробництва, яким держава має надавати селективну підтримку - так звані точки зростання. Наступним кроком до стимулювання розвитку інноваційної діяльності є створення умов для підвищення доходів працюючого населення, що сприятиме підвищенню купівельного попиту. Однак і тут необхідно змінити пріоритети: в матеріальній оцінці праці ввести коефіцієнт інтелектуалізації праці, максимальне значення якого має знаходитися у галузі освіти і науки. Крім того, важливо визначити перспективні наукові напрями і забезпечити їх матеріальнотехнічною та лабораторною базою, інформаційними комунікаціями, кадрами і гарантіями впровадження отриманих результатів у промислове освоєння і поширення у вигляді торгівлі інтелектуальною власністю.

Особливої уваги з боку органів державної влади потребує створення повноцінної інфраструктури підтримки інноваційної діяльності, розподільної і накопичувальної системи (банки, страхові компанії, пайові та пенсійні фонди, фондовий ринок тощо). Треба дати інвесторам можливість управляти ризиками, для чого запропонувати їм адекватні фінансові інструменти. Доцільно стимулювати розвиток ф’ючерсних і опціонних ринків. Усі сформульовані вище пропозиції дозволяють побудувати модель державного регулювання інноваційної діяльності підприємництва (рис. 2).

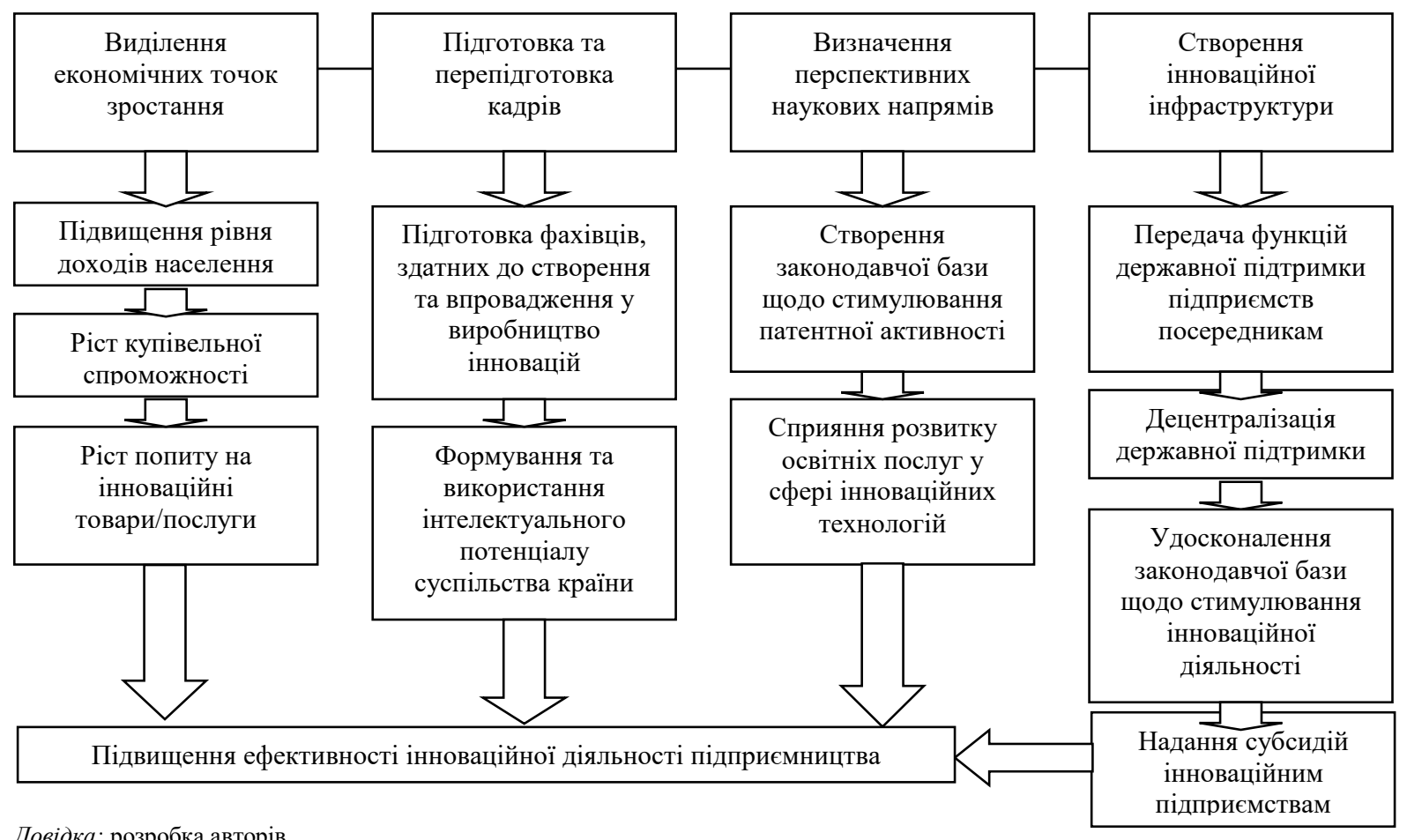

Рис. 2. Модель державного регулювання інноваційної діяльності підприємництва 
Слід зазначити, що ефективність державного регулювання інноваційної діяльності підприємництва знаходиться у прямій залежності від рівня регулювання розвитком інтелектуального потенціалу країни. Ми погоджуємося з думкою М.Семикіної та В.Гунько про те, що інтелектуальний потенціал країни являє собою сукупність усіх інтелектуальних ресурсів, враховуючи людей, їх знання, інтелектуальні здібності, нематеріальні активи, які характеризують сукупні інтелектуальні можливості, що можуть бути

використані у процесі функціонування економіки, перетворюючись в інтелектуальний капітал [15, с. 53]. У зв'язку з цим, підвищення рівня інтелектуального потенціалу суспільства буде сприяти розширенню інноваційної діяльності підприємств у країні. Саме тому важливим та стратегічно необхідним $\epsilon$ здійснення рівня регулювання розвитку інтелектуального потенціалу країни. Розглянемо можливу математичну модель розрахунку ефективності зазначеного регулювання

Формалізовано ефективність можна відобразити таким чином:

$$
Y_{1}=f(E P)=\frac{k_{1} e_{1}+k_{2} e_{2}+k_{3} e_{3}}{3},
$$

де $E P$ - агрегований індекс розвитку освіти;

$k_{1}, k_{2}, k_{3}$ - коефіцієнти рівня освіти, що відображають співвідношення даного показника у країні, що досліджується, до показника світового рівня розвинених країн;

$e_{1}$ - індекс загальної освіти у населення;

$e_{2}$ - чисельність студентів у розрахунку на 1000 осіб населення;

$e_{3}$ - рівень витрат на освіту у $\%$ до розміру ВВП.

$$
Y_{2}=f(S P)=\frac{a_{1} s_{1}+a_{2} s_{2}}{2},
$$

де $S P$ - агрегований індекс розвитку науки;

$a_{1}, a_{2}$ - коефіцієнти рівня розвитку науки, що відображають співвідношення даного показника у країні, що досліджується, до показника світового рівня розвинених країн;

$s_{1}$ - питома вага робітників, зайнятих у науці;

$s_{2}-$ витрати на науку.

Також пропонуємо ввести два коефіцієнти витрат на створення інтелектуального потенціалу $p_{1}, p_{2}$, що відображають співвідношення рівня зміни витрат на реалізацію задач одного рівня у країні, що досліджується, та країнах, що займають провідне місце у світовій економіці. Зазначені коефіцієнти розраховуються таким чином:

$$
p_{1}=\frac{Q_{b}}{Q_{b}^{\prime}} ; p_{2}=\frac{Q_{s}}{Q_{s}^{\prime}},
$$

де $Q_{s}-$ витрати на зміни в освіті у країні, що досліджується;

$Q_{6}^{\prime}-$ витрати на зміни в освіті у розвинених країнах;

$Q_{s}$ - витрати на зміни у науці у країні, що досліджується;

$Q_{s}^{\prime}$ - витрати на зміни у науці у розвинених країнах.

3 огляду на викладене вище, ефективність регулювання інтелектуальним потенціалом буде визначатися таким чином:

$$
E=\frac{Y_{1}}{p_{1} Q}+\frac{Y_{2}}{p_{2} Q},
$$

де $Q$ - витрати на створення інтелектуального потенціалу суспільства, що враховують витрати на науку та освіту в цілому протягом періоду, що досліджується.

Запропонована математична модель розрахунку ефективності регулювання розвитку інтелектуального потенціалу суспільства дозволяє розробляти системи регулювання із заданою ефективністю, а також прогнозувати агреговані індекси інтелектуального потенціалу країни (або окремого їі регіону) на основі перспективних планів розвитку та прогнозованих бюджетних показників.

Висновки та перспективи подальших досліджень. Проведене дослідження надає можливість стверджувати, що розвиток інноваційної діяльності підприємництва сприяє підвищенню конкурентоспроможності економіки країни на світовому рівні, а також забезпечує ії сталий розвиток у цілому. Саме тому державне регулювання має бути спрямоване на розробку заходів, що забезпечували б: активізацію інноваційної діяльності у науково-технічній сфері; розвиток телекомунікацій та інформаційних систем; створення сучасної інтегрованої інфраструктури підтримки творчої активності суспільства; розвиток інформаційних технологій в управлінні та проектуванні тощо. Зазначене дасть можливість задовольнити економічні інтереси усіх суб'єктів господарювання за рахунок упровадження та примноження науково-технічного та інтелектуального потенціалу країни. 


\section{Список використаної літератури:}

1. Бірюченко С.Ю. Мотиваційна складова активізації інноваційного розвитку підприємств промисловості / С.Ю. Бірюченко // Вісник ЖДТУ. Економіка, управління та адміністрування [Електронний ресурс]. - Режим доступу : https://doi.org/10.26642/jen-2019-1(87)-3-8.

2. Коюда В.О. Інноваційна діяльність підприємства та оцінка ії ефективності : монографія / В.O. Коюда, Л.А. Лисенко. - Х. : ФОП Павленко О.Г. ; ВД «ІНЖЕК», 2010. - 224 с.

3. Крикуненко Д.О. Проблеми впровадження інновацій на підприємствах / Д.О. Крикуненко // Маркетинг і менеджмент інновацій. - 2011. - № 4. - С. 45-49.

4. Маслак О.О. Чинники впливу на інноваційну діяльність промислових підприємств / О.О. Маслак, К.О. Дорошкевич // Науковий вісник НЛТУ України. - 2012. - Вип. 22. - С. 269-274.

5. Drucker P. Innovation and Entrepreneurship / P.Drucker. - London : Harper Collins Publishers Ltd. - 1993. - 269 p.

6. Тарасова О.В. Теоретико-методологічні основи інноваційної діяльності підприємств / О.В. Тарасова // Економіка харчової промисловості. - 2012. - № 1. - С. 37-41.

7. Фатхутдинов Р.А. Инновационный менеджмент / Р.А. Фатхутдинов. - СПб. : Питер пресс, 2008. - 442 с

8. Чумак Л.Ф. Інноваційна діяльність підприємства в сучасних умовах / Л.Ф. Чумак // Бізнес Інформ. - 2012. - № 12. C. 209-212.

9. Schumpeter J. Capitalism, Socialism, and Democracy / J.Schumpeter. - London : Allen and Unwin (Publishers) Ltd, 1976. $-460 \mathrm{p}$.

10. Амоша А. Інноваційний шлях розвитку України: проблеми та рішення / А.Амоша // Економіст. -2005. - № 6. C. $28-32$.

11. Бурлака В. Пріоритети інноваційного розвитку в українській економіці / В.Бурлака // Діловий вісник. - 2010. № 12 (199). - C. 18-22.

12. Кукса I.M. Державні важелі активізації зарубіжної інвестиційної активності в контексті розвитку національної економіки / I.M. Кукса // Актуальні проблеми економіки. - 2014. - № 2 (152). - С. 75-78.

13. Мойсеєнко І.П. Регресійний аналіз інтелектуального потенціалу / І.П. Мойсеєнко, М.Я. Демчишин // Актуальні проблеми економіки. - 2008. - № 10. - С. 142-148.

14. Полішук О.О. Сутність поняття «інноваційна діяльність» як соціально-економічної категорії / О.О. Поліщук // Економічний вісник Донбасу. - 2010. - № 3 (21). - С. 169-171.

15. Семикіна М.B. Інтелектуальний потенціал та його роль в національній економіці / М.B. Семикіна, B.I. Гунько // Экономика и управление : научно-практический журнал. - 2011. - № 1. - С. 50-56.

16. Файчук О.М. Інноваційний процес як рушійна сила економічного зростання / О.М. Файчук, О.В. Файчук // Бізнес Інформ. - 2013. - № 10. - С. 66-70.

17. Федулова Л.І. Проблеми і передумови формування в Україні економіки новітнього технологічного укладу / Л.І. Федулова // Управлінські інновації. - 2012. - Вип. 1. - С. 9-20.

18. Gnatenko I. Architectonics of the concept of the national labour market regulation / I.Gnatenko, V.Rubezhanska, // Journal «Management» [Electronic resource]. - Access mode : https://doi.org/10.30857/2415-3206.2018.1.7.

19. Гнатенко I.A. Феномен інноваційного підприємництва в національній економіці / I.A. Гнатенко // Науковий вісник УНУ. Міжнародні економічні відносини та світове господарство. - 2019. - № 23. - С. 61-64.

\section{References:}

1. Biryuchenko, S.Yu. (2019), «Motyvacijna skladova aktyvizacii' innovacijnogo rozvytku pidpryjemstv promyslovosti», Visnyk ZDTU. Ekonomika, upravlinnya ta administruvannya, No. 1 (87), pp. 3-8, [Online], available at: https://doi.org/10.26642/jen-2019-1(87)-3-8

2. Koyuda, V.O. and Lisenko, L.A. (2010), Innovacijna dijal'nist' pidpryjemstva ta ocinka i'i' efektyvnosti , monografija, FOP Pavlenko O.G., VD «INZhEK», Xarkiv, 224 p.

3. Krykunenko, D.O. (2011), «Problemy vprovadzhennya innovacij na pidpryyemstvah», Marketyng i menedzhment innovacij, No. 4, pp. 45-49.

4. Maslak, O.O. and Doroshkevich, K.O. (2012), «Chynnyky vplyvu na innovacijnu diyal'nist promyslovyh pidpryyemstv», Naukovyj visnyk NLTU Ukrai'ny, Vol. 22, pp. 269-274.

5. Drucker, P. (1993), Innovation and Entrepreneurship, Harper Collins Publishers Ltd., London, 269 p.

6. Tarasova, O.V. (2012), «Teoretyko-metodologichni osnovy innovacijnoyi diyal’nosti pidpry`yemstv», Ekonomika harchovoyi promyslovosti, No. 1, pp. 37-41.

7. Fatkhutdinov, R.A. (2008), Innovatsionnyi menedzhment, Piter press, SPb., 442 p

8. Chumak, L.F. (2012), «Innovacijna dijal'nist' pidpryjemstva v suchasnyh umovah», Biznes Inform, No. 12, pp. 209-212.

9. Schumpeter, J. (1976), Capitalism, Socialism, and Democracy, Allen and Unwin (Publishers) Ltd., London, 460 p.

10. Amosha, A. (2005), «Innovacijnyj shljah rozvytku Ukrai'ny: problemy ta rishennja», Ekonomist, No. 6, pp. 28-32.

11. Burlaka, V. (2010), «Priorytety innovacijnogo rozvytku v ukrai'ns'kij ekonomici», Dilovyj visnyk, No. 12 (199), pp. 18-22.

12. Kuksa, I.M. (2014), «Derzhavni vazheli aktyvizacii' zarubizhnoi' investycijnoi' aktyvnosti v konteksti rozvytku nacional'noi' ekonomiky», Aktual'ni problemy ekonomiky, No. 2 (152), pp. 75-78.

13. Mojseyenko, I.P. and Demchishin, M.Ja. (2008), «Regresijnyj analiz intelektual'nogo potencialu», Aktual`ni problemy ekonomiky, No. 10, pp. 142-148.

14. Polishhuk, O.O. (2010), «Sutnist' ponjattja «innovacijna dijal'nist'» jak social'no-ekonomichnoi' kategorii'», Ekonomichnyj visnyk Donbasu, No. 3 (21), pp. 169-171. 
15. Semykina, M.V. and Gun'ko, V.I. (2011), «Intelektual'nyj potencial ta jogo rol' v nacional'nij ekonomici», Ekonomika i upravlenie, nauchno-prakticheskii zhurnal, No. 1, pp. 50-56.

16. Fajchuk, O.M. and Fajchuk, O.V. (2013), «Innovacijny`j proces yak rushijna sy`la ekonomichnogo zrostannya», Biznes Inform, No. 10, pp. 66-70.

17. Fedulova, L.I. (2012), «Problemy i peredumovy formuvannja v Ukrai'ni ekonomiky novitn'ogo tehnologichnogo ukladu», Upravlins'ki innovacii', Vol. 1, pp. 9-20.

18. Gnatenko, I. and Rubezhanska, V. (2018), «Architectonics of the concept of the national labour market regulation», Journal «Management», No. 1 (27), pp.79-91, [Online], available at: https://doi.org/10.30857/2415-3206.2018.1.7

19. Gnatenko, I.A. (2019), «Fenomen innovacijnogo pidpryjemnyctva v nacional'nij ekonomici», Naukovyj visnyk UNU. Mizhnarodni ekonomichni vidnosyny ta svitove gospodarstvo, No. 23, pp. 61-64.

Орлова-Курилова Ольга Володимирівна - кандидат економічних наук, доцент кафедри менеджменту, статистики та економічного аналізу Луганського національного аграрного університету.

ORCID: https://orcid.org/0000-0001-8382-8070

Наукові інтереси:

- державне регулювання інноваційного підприємництва;

- управління інноваційними кластерами.

E-mail: orlovakur73@gmail.com

Гнатенко Ірина Анатоліївна - кандидат економічних наук, доцент, докторант Київського національного університету технологій та дизайну.

ORCID: https://orcid.org/0000-0002-0254-2466

Наукові інтереси:

- інноваційний розвиток підприємництва на засадах кластерного партнерства;

- державне регулювання інноваційних процесів в економіці.

E-mail: q17208@ukr.net

Рубежанська Вікторія Олегівна - кандидат економічних наук, асистент кафедри фінансів, обліку та банківської справи Луганського національного університету імені Тараса Шевченка.

ORCID: https://orcid.org/0000-0001-8047-4000

Наукові інтереси:

- інноваційне підприємництво;

- адаптивні механізми регулювання ринку праці.

E-mail: rubezhiik@gmail.com 